This item was submitted to Loughborough's Research Repository by the author.

Items in Figshare are protected by copyright, with all rights reserved, unless otherwise indicated.

\title{
Mountbatten, Auchinleck and the end of British Indian Army: August- November 1947
}

PLEASE CITE THE PUBLISHED VERSION

PUBLISHER

Edinburgh University Press

VERSION

AM (Accepted Manuscript)

PUBLISHER STATEMENT

This is an Author's Accepted Manuscript of an article published by Edinburgh University Press in Britain and the World. The Version of Record is available online at:

https://www.euppublishing.com/doi/full/10.3366/brw.2019.0325.

\section{LICENCE}

CC BY-NC-ND 4.0

\section{REPOSITORY RECORD}

Ankit, Rakesh. 2019. "Mountbatten, Auchinleck and the End of British Indian Army: August-november 1947". figshare. https://hdl.handle.net/2134/35103. 
Mountbatten, Auchinleck and the end of British Indian Army: August-November 1947

\begin{abstract}
Juxtaposing the private papers of Louis Mountbatten and Claude Auchinleck, this article seeks to illuminate the crux at the centre of the reconstitution of the British Indian army into Indian and Pakistani armies, namely, their worsening relationship between April and November 1947, in view of what they saw as each other's partisan position and its consequences, the closure of Auchinleck’s office and his departure from India. In doing so in considerable detail, it brings to fore yet another aspect of that fraught period of transition at the end of which the British Indian Empire was transformed into the dominions of India and Pakistan and showcases the peculiar predilections in which the British found themselves during the process of transfer of power.
\end{abstract}

\title{
Word Count: 9900 (excluding foot-notes)
}

\section{Keywords: Mountbatten, Auchinleck, Partition, British Indian Army}

\section{Introduction}

‘Army may be split into two parts' - proclaimed the Daily Telegraph in London on 4 June 1947, a day after the announcement of the plan that partitioned the British empire in India. ${ }^{1}$ This division or 'reconstitution', as it was softly termed, of the British Indian Army turned out to be one of the most contested aspects of the 'breaking up' of India. ${ }^{2}$ It was a matter of the highest sensitivity for the two emerging dominions, beset by mistrust between their political leaderships. It acquired a still more special significance in the wake of worsening

\footnotetext{
${ }^{1}$ Yasmin Khan, The Great Partition: The Making of India and Pakistan (New Haven, 2007), p. 96.

${ }^{2}$ See Anwesha Sengupta, 'Breaking Up: Dividing Assets between India and Pakistan in times of Partition', The Indian Economic \& Social History Review, 51: 4 (2014), pp. 529-548.
} 
inter-communal relations in the subcontinent in August-September, followed by the possibilities of outright inter-dominion conflict in the princely states of Junagadh and Jammu and Kashmir over September-October. ${ }^{3}$ Among the key personalities on whose personal equations and political positions hinged this 'reconstitution' were Lord Louis Mountbatten, the last Viceroy of British India and first Governor-General of independent India and Field Marshal Claude Auchinleck, the last Commander-in-Chief of British Indian Army and first Supreme Commander of Armed Forces in India and Pakistan. They, as Thomas Elmhirst, first Air Chief Marshal of independent India, wrote, did not 'ever [see] quite eye to eye'. ${ }^{4}$

In the accumulated literature on partition and its many aspects, not nearly enough has been written on the process of partition, that is, the division of assets of British India between its succeeding dominions. ${ }^{5}$ Within this process, the individual imprimatur of Mountbatten and Auchinleck, with their worsening mutual relations, had implications, which have gone lightly remarked. The first British literary wave on partition comprised essentially participatory

\footnotetext{
${ }^{3}$ On the former see Vazira Zamindar, The Long Partition and the Making of Modern South Asia (New York, 2007); for the latter, see Rakesh Ankit, 'The accession of Junagadh, 1947-48: Colonial Sovereignty, State Violence and post-Independence India’, The Indian Economic \& Social History Review, 53 : 3 (2016), pp. 371404 and The Kashmir Conflict: From Empire to the Cold War, 1945-66 (London, 2016).

${ }^{4}$ Thomas Elmhirst, Recollections; privately published by RT Roger Elmhirst (1991), Churchill Archives Centre, Churchill College, Cambridge, p. 110.

${ }^{5}$ For exceptions see Ranbir Samaddar, The Marginal Nation (Delhi, 1999), Tan Tai Yong and Gyanesh Kudaisya, eds., Partition and Post-colonial South Asia (London, 2007), Joya Chatterji, The Spoils of Partition: Bengal and India, 1947-67 (Cambridge, 2007), Duncan McLeod, India and Pakistan: Friends, Rivals or Enemies (Aldershot, 2008) and Pallavi Raghavan, 'The Finality of Partition: Bilateral Relations between India and Pakistan, 1947-57', PhD Dissertation, (University of Cambridge, 2012).
} 
account(s) especially focussed around Mountbatten and his great 'mission' ${ }^{6}$ Then, there were the reminiscences of Indian and Pakistani politicals, which were directed more towards each other, though in Pakistan there was expressed greater bitterness towards Mountbatten. ${ }^{7}$ Professional historians came upon the scene in late-1960s, ${ }^{8}$ and the historical scholarship burgeoned in the 1970s and 1980s, following the release of official documents in Britain. ${ }^{9}$ Located firmly within the discourses of 'decolonisation and nationalism(s)', the emerging literary corpus focussed on constitutional developments and communal deterioration in India and analysed the 'strategy(s)' of the British, the Indian National Congress and the All-India Muslim League. ${ }^{10}$

With respect to the future of the British Indian Army, the treatment was limited to a largely unanimous expression of the rather improbable British desire of a united Indian army in a divided India, which was opposed by the League's insistence that the 'British Indian army should be divided'. ${ }^{11}$ Otherwise, it was feared that Pakistan would 'collapse like a pack of

\footnotetext{
${ }^{6}$ See, for instance, Alan Campbell-Johnson, Mission with Mountbatten (London, 1951), EWR Lumby, The Transfer of Power in India, 1945-7 (London, 1954), Penderel Moon, Divide and Quit (Berkeley, 1962) and HV Hodson, The Great Divide: Britain-India-Pakistan (London, 1969).

${ }^{7}$ For example, VP Menon, The Transfer of Power in India (Bombay, 1957) and Chaudhry Muhammad Ali, The Emergence of Pakistan (New York, 1967).

${ }^{8}$ With the publication of CH Phillips and Mary Wainwright, ed., The Partition of India: Policies and Perspectives, 1935-1947 (London, 1970).

${ }^{9}$ See the classic trinity by RJ Moore, Escape from Empire: The Attlee Government and the Indian Problem (Oxford, 1983), Making the New Commonwealth (Oxford, 1987) and Endgames of Empire (Oxford, 1988).

${ }^{10}$ For a discussion of the place of partition in South Asian histories see Tan Tai Yong and Gyanesh Kudaisya, The Aftermath of Partition in South Asia (London, 2000), pp. 9-19.

${ }^{11}$ Anita Inder Singh, The Origins of the Partition of India 1936-1947 (Oxford, 1987), p. 227.
} 
cards'. ${ }^{12}$ The narrative was established that this led to the setting up of a Supreme Commander’s Headquarters and a Joint Defence Council, which divided the army and from which Auchinleck had to step down 'following Indian complaints that he favoured Pakistani interests'. ${ }^{13}$ The consequence was acknowledged that the process of division of equipment and stores did not go smoothly, thereby putting Pakistan at a disadvantage. The outbreak of hostilities in Kashmir further hindered this division. When the revisionist 'high politics' literature moved towards a critical interpretation of Mountbatten’s role in 1947, it coalesced around three issues: his alleged interference with the judicial independence of the Cyril Radcliffe Boundary Commission, his hastening of the date of Partition and concomitant failure in provisioning adequate safeguards against communal violence and his subsequent Governor-General-ship of India, where his closeness with Jawaharlal Nehru led to his partisan attitude on the Kashmir dispute. ${ }^{14}$

Since the late-1980s, studies of 1947 rightly became 'regional' and then from 1990s, devoted to the tragic 'human dimension' of partition, they further moved beyond all-India characters and concerns. ${ }^{15}$ In the last decade, the broader, over-arching narrative approach has made a return among studies of partition and its long afterlife in South Asia. ${ }^{16}$ However,

\footnotetext{
${ }^{12}$ Ayesha Jalal, The State of Martial Rule: the Origins of Pakistan's Political Economy of Defence (Cambridge, 1990), p. 38.

${ }^{13}$ Ian Talbot and Gurharpal Singh, The Partition of India (Cambridge, 2009), p. 158.

${ }^{14}$ See Andrew Roberts, Eminent Churchillians (London, 1994) and Lucy Chester, Borders and Conflict in South Asia: The Radcliffe Boundary Commission and the Partition of Punjab (Manchester, 2013).

${ }^{15}$ For a discussion of the more recent trends in the evolution of the partition historiography see Talbot and Singh, The Partition of India, pp. 8-23.

${ }^{16}$ See, for popular examples, Alex von Tunzelmann, Indian Summer: The Secret History of the End of Empire (London, 2007) and Nisid Hajari, Midnight Furies: The Deadly Legacy of India’s Partition (New Delhi, 2015).
} 
Mountbatten continues to be largely approached along the old axis of boundary award, communal violence and princely states, while Auchinleck continues to be noted for his 'attachment to the unity of the Indian army', which, therefore, gave him 'sleepless nights' at the prospect of its division. ${ }^{17}$ The greater emphasis remains on the significance for India and Pakistan, of the fact that 'national leaders publicly countenanced this [the division of the army] only after the decision to partition', with the consequent 'sudden, complicated and deliberately vague' untangling. ${ }^{18}$ In the recently emerged literature on the 'Indian Army and the End of the Raj', the 'Military and Indian Democracy since Independence', and, 'Pakistan and its Army', the interregnum of August-November 1947, when Auchinleck's tenure at the head of the British Indian Army had not ended, Indian dominion and democracy had not begun and Pakistan's army was not stabilised, gets reduced to no more than either an epilogue or a prologue. ${ }^{19}$ The global turn in military history-writing around British Indian Army's involvement in the Second World War has even less to remark, naturally, on this liminal episode on the break-up of that vaunted military machine, ${ }^{20}$ which also gets over-

\footnotetext{
${ }^{17}$ Khan, The Great Partition, p. 97 and Stanley Wolpert, Shameful Flight: the Last Years of the British Empire in India (Oxford, 2006), p. 156.

${ }^{18}$ Khan, The Great Partition, p. 96

${ }^{19}$ See Daniel Marston, The Indian Army and the End of the Raj (Cambridge, 2014), Steven Wilkinson, Army and Nation: The Military and Indian Democracy since Independence (Harvard, 2015) and Shuja Nawaz, Crossed Swords: Pakistan, its Army and Wars within (Karachi, 2008).

${ }^{20}$ See, for examples, Srinath Raghavan, India's War: the Making of Modern South Asia, 1939-45 (New Delhi, 2016) and Yasmin Khan, The Raj at War: A People's History of India's Second World War (London, 2015).
} 
shadowed in the histories of nation-states in India and Pakistan since 1947, which begin properly from 1950s. ${ }^{21}$

This article seeks to address this gap by focusing on the crux at the centre of the 'reconstitution' of the British Indian Army into Indian and Pakistani armies, namely, the deteriorating relationship of Mountbatten and Auchinleck between April and November 1947. Mining their private papers, supplementing them with papers of those sympathetic to them, like the soldier Hastings Ismay and the diplomat Laurence Grafftey-Smith respectively, and drawing upon published memoirs and correspondences, it presents in considerable detail, what they saw as each other's partisan position and probes its major consequence: the preponed closure of Auchinleck's office and his early departure from India. In doing so, it throws light on another odd aspect of that fraught period of transition from the British Indian Empire to the dominions of India and Pakistan and shows yet more of the peculiar predilections in which the withdrawing British got embroiled.

Between 14 August and 30 November 1947, the situation in the divided subcontinent deteriorated dramatically. Violence raged across North India especially in and around the national capital region of New Delhi. ${ }^{22}$ It was accompanied with a stupendous-scale migration of people; rendering imperial subjects overnight into refugees before they could

\footnotetext{
${ }^{21}$ See Ramachandra Guha, India after Gandhi (London, 2007), Ian Talbot, Pakistan: A New History (London, 2012), Ted Svensson, Production of Post-colonial India and Pakistan: Meanings of Partition (London, 2013) and Gyan Prakash et al, eds., The Postcolonial Moment in South and Southeast Asia (London, 2018). ${ }^{22}$ See Gyanendra Pandey, 'Partition and Independence in Delhi: 1947-48', Economic and Political Weekly, 32: 36 (Sep. 6-12, 1997), pp. 2261-2272.
} 
become citizens. ${ }^{23}$ It was joined, in early-September, by the crisis of accession in the princely state of Junagadh in western India taking a military turn. ${ }^{24}$ Then, the simmering dispute in the princely state of Jammu and Kashmir broke-out into a proper conflict in end-October. ${ }^{25}$ At the heart of these events, which eclipsed early India-Pakistan relations, was a breakdown of the colonial apparatus, in transition to serve its post-colonial successors. Even as the process of partitioning assets and the army was far from complete, a vortex of war-like mobilisation had begun in Kashmir, Punjab and Kathiawar. While the nationalists on both sides were engaged in the latter, it was men like Mountbatten and Auchinleck, who were presiding over the former; a process that was at the heart of the successful, if bloody, end of empire and stable, if unequal, emergence of its successor dominions: India inherited '14/20 armoured regiments, 40/48 artillery regiments, 21/29 infantry regiments, larger part of the air force and navy and 137, 000/160, 000 tonnes of ordinance'. ${ }^{26}$

By showing this process through the papers of Mountbatten, Auchinleck and others, this article, firstly, seeks to contribute to existing understanding of the origins of the conflictual relations between India and Pakistan. More than that, it aims to illuminate the embroiled nature of the British withdrawal wherein it was the British personalities at odds with each other, who too contributed to make it a partisan process of partition. Finally, it attempts to illustrate the uneasy coexistence of certain British officials and Indian politicals especially on

\footnotetext{
${ }^{23}$ See Taylor Sherman, William Gould and Sarah Ansari, eds., From Subjects to Citizens: Society and the Everyday State in India and Pakistan, 1947-1970 (Cambridge, 2014).

${ }^{24}$ See Rakesh Ankit, 'Junagadh, India and the Logic of Occupation and Appropriation, 1947-49', Studies in History, 34: 2 (2018), pp. 109-140.

${ }^{25}$ See Christopher Snedden, Kashmir: The Untold Story (Delhi, 2013).

${ }^{26}$ Perry Anderson, The Indian Ideology (London, 2013), p. 67.
} 
the three-fold question of first nationalisation, then partition and their respective psychological impacts on the morale of a colonial army, employment of Indian troops abroad for various purposes, and the day-to-day functioning of the Defence Department, about which Nehru and his colleagues protested at being kept 'in the dark', from even before the transfer of power. ${ }^{27}$ Afterwards, as two nations strove to establish their states and armies, Britons were either subsumed in one or the other like Mountbatten in India or remained 'supranational' like Auchinleck, ${ }^{28}$ leading to a strained triangular transmission of power.

\section{Prelude}

Mountbatten and Auchinleck first came together on the question of British Indian Army long before the events of 1947. In January 1944, Auchinleck's beloved Indian Army was under fire from American war correspondents, who were questioning whether Indian troops would fight for the British in South-east Asia, especially Burma. ${ }^{29}$ It was slanderous considering the stellar record of the British Indian Army right from the days of the First World War. To counter this mischievous propaganda, Auchinleck requested Mountbatten to send some of the senior US officers under his South East Asia Command to visit Indian units and see them at work. ${ }^{30}$ Auchinleck cautioned Mountbatten's headquarters that the politically motivated American correspondents were not as friendly towards the British, given the anti-colonial

\footnotetext{
${ }^{27}$ National Archives of India (NAI). Cabinet Secretariat. File No. 114/CF/46, 18 September 1946.

${ }^{28}$ John Connell, Auchinleck (London, 1959), p. 913.

${ }^{29}$ Hartley Library (HL), University of Southampton. MB1/C136 (Folder 1), Mountbatten Papers. No. 1, Halifax (Washington) to War Department (New Delhi), 3 January 1944.

${ }^{30}$ HL. MB1/C136 (Folder 1). Mountbatten Papers. DO No. 80/M-3/23, Auchinleck to Mountbatten, 5 January 1944.
} 
movement of the India League and the Congress in America, the shift in political climate since the signing of the Atlantic Charter and the criticism of the British in the devastating Bengal famine of 1943. ${ }^{31}$ To Auchinleck, they appeared to obstruct Mountbatten’s South East Asia Command by causing differences with the American forces under General Stilwell thus hurting inter-allied relations. ${ }^{32}$ Mountbatten responded as only he could to this propaganda war. A 'more than grateful' Auchinleck profusely thanked him for he 'could not have done more'. In words which would seem ironic three years hence, Auchinleck wrote:

\footnotetext{
Personally, I do not mind what they say about me but these totally unfounded and unjustifiable accusations and innuendoes cannot fail to have a profoundly unsettling effect in India because the whole credit of the Army and myself must be lowered and their confidence reduced...Y You could not have been more generous or open and I appreciate very deeply.. ${ }^{33}$
}

Over the next couple of years, Auchinleck kept in touch with Mountbatten apprising him of the creeping politicisation, discontent, indiscipline and demoralisation in the Indian Army, reflecting the growing stronger political feeling in India. ${ }^{34}$ When Mountbatten raised the question of employing the Indian troops to restore French and Dutch regimes in the face of nationalist opposition in South-East Asia, Auchinleck was wary 'to disregard political feeling

\footnotetext{
${ }^{31}$ On this, see Auriol Weigold, Churchill, Roosevelt and India: Propaganda during World War II (London, 2008).

${ }^{32}$ HL. MB1/C136 (Folder 2). Mountbatten Papers. DO No. 80/S-1, Auchinleck to Lt General Henry Pownall, 7 March 1944.

${ }^{33}$ HL. MB1/C138. Mountbatten Papers. DO No. 80/M-3/41, Auchinleck to Mountbatten, 29 April 1944.

${ }^{34}$ HL. MB1/C144. Mountbatten Papers. DO No. 80/M-3/II, Auchinleck to Mountbatten, 6 September 1945.
} 
in India' and of the risk of instability that it entailed. ${ }^{35}$ A soldier's son, Auchinleck's repeated ‘intermission with politicians’ in both Britain and India, during war and in its absence, had been difficult. ${ }^{36}$ Being the $\mathrm{C}$-in-C at a time of post-WWII transition with 'vast changes coming upon India' during which 'it was no longer possible for Indian Army to stand aloof from politics', Auchinleck would find himself as 'the pivot of a fierce political battle', most dramatically manifested by 'the INA Trials'. ${ }^{37}$ Alongside it, the vexed question of the continued 'use of Indian troops abroad' and their consequent 'withdrawal' from overseas, evolved from September 1946, when the Interim Government under Jawaharlal Nehru came into office. ${ }^{38}$ In a cabinet meeting of 18 September 1946, Nehru protested to the-then Viceroy Archibald Wavell against 'the telegram from the Burma Command to Auchinleck suggesting that if the situation in Burma took a serious turn it might be necessary to use Indian troops for maintaining order and essential supplies'. Nehru urged Wavell to inform London 'of our feeling that Indian troops should not be used against Burmans and, in any case, not for the suppression of industrial strikes or political movement'. Wavell tried to deflect this by bringing up the 'considerable number of Indians in Burma [who] have to be given protection'. Nehru responded by broadening the question and asking for an examination of 'the larger quantities of Indian troops being sent abroad for various

\footnotetext{
${ }^{35}$ HL. MB1/C140 (Folder 2). Mountbatten Papers. DO No. 80/M-3/II, Auchinleck to Mountbatten, 14 October 1945; Connell, Auchinleck, Auchinleck to Wavell, 13 November 1945, p. 824.

${ }^{36}$ Connell, Auchinleck, p. 3, 305, 593, 862.

${ }^{37}$ Ibid. p. 785; on the INA trials see pp. 794-819. Also, AG Noorani, Indian Political Trials, 1775-1947 (Delhi, 2006).

${ }^{38}$ See Rakesh Ankit, Jawaharlal Nehru’s Interim Government, 1946-47: an Alternative Historical Assessment, Nehru Memorial Museum and Library, New Delhi, History and Society New Series No. 80, September 2015.
} 
purposes' ${ }^{39}$ At this time, the number of Indian troops serving outside India show the extent of concern for Wavell and Auchinleck: Japan (11400), Hong Kong (5800), Malaya (59000), Burma (78500), Siam (4000), Borneo (1000), Ceylon (1500), Iraq (16000), Middle-East (12500), Italy (400). ${ }^{40}$

\section{February-August 1947}

Mountbatten's Chief of Staff Hastings Ismay called the communal breaking up of the Indian Army 'the biggest crime...the biggest headache' and 'the problem which caused many of us the greatest grief'. ${ }^{41}$ It emerged once the forthcoming transfer of power in India was announced by Prime Minister Clement Attlee on 20 February 1947 and Mountbatten was charged with the responsibility of overseeing it. Ismay, himself a 'subaltern in India' and an old friend, had served alongside Auchinleck in 1923 at Simla, where 'a great future was prophesied' for Auchinleck. ${ }^{42}$ He would have a ring-side view of the strained relations of a 'shy, sensitive and introvert' Auchinleck with the 'extrovert' Winston Churchill over the Middle-East during the Second World War that ultimately led to his removal from there to India by August 1942. ${ }^{43}$ In March 1947, as Ismay arrived in India and met with Auchinleck, both agreed initially that for the future of British officers and other ranks in Indian Army, it was of paramount importance to retain its essential unity. Later, Mountbatten would accept

\footnotetext{
${ }^{39}$ Nicholas Mansergh, EWR Lumby and Penderel Moon, ed., The Transfer of Power (TOP), 1942-47 (London, 1970-83), Volume VIII, Nehru to Wavell, Item No. 331, pp. 538-39.

${ }^{40}$ The National Archives (TNA). PREM 8/541/6. Auchinleck’s note, 5 September 1946.

${ }^{41}$ The Memoirs of Lord Ismay (London: Heinemann, 1960), p. 425.

${ }^{42}$ Ibid. p. 3, 40.

${ }^{43}$ Ibid. p. 269, 276.
} 
the inevitable 'sooner' and easier than the Commander-in-Chief, ${ }^{44}$ as he had not been associated with the Indian Army for over forty years. ${ }^{45}$ Still, Ismay would credit Auchinleck and his staff with 'ingenious planning' for the partition of the Army. ${ }^{46}$ Auchinleck's own regiment from 1904, the $1^{\text {st }}$ Punjab, was 'half Muslim, a quarter Sikh and a quarter Rajput' and its division meant for him a sad denouement of 'all those links which he had spent a lifetime creating'. His last command as C-in-C was 'markedly reticent': 'Discontinuance of Indian Army Orders. This is the last India Army Order'. ${ }^{47}$

A key aspect of this discontinuance, as seen above, was the withdrawal of Indian troops from abroad. By February 1947, Nehru and his colleagues were insisting on the withdrawal of troops from Egypt and Palestine immediately, reduction from 14, 000 troops to 8, 000 in Iraq, withdrawal of 10, 440 Indian occupation force from Japan as soon as possible and withdrawal of troops from Burma and Malaya, 'at their convenience'. ${ }^{48}$ Their desire reflected the recommendations of Defence Secretary ADF Dundas’ summary note of 14 February 1947, conceding to 'public opinion, good neighbourliness and friendly relationship', and Defence Member Baldev Singh’s emphasis on 'national interests' as against 'empire considerations'. These latter, the legacies of which could not be shedded immediately amounted to the presence of 27, 500 Indian troops in Burma, 26, 000 in Malaya, 3000 in Egypt and Palestine, 14, 000 in Iraq, 10, 440 in Japan, with others being Borneo - 300, Hong Kong - 1000, and, Ceylon - 300. Except in Japan, the cost of Indian troops abroad was being borne by London

\footnotetext{
${ }^{44}$ Philip Ziegler, Mountbatten: The Official Biography (London, 1985), p. 389.

${ }^{45}$ See item nos. 108, 126, 159, 213, 239 in volume XI of (TOP), 1942-47.

46 The Memoirs of Lord Ismay (London: Heinemann, 1960), p. 428.

${ }^{47}$ Cornell, Auchinleck, p. 898.

${ }^{48}$ National Archives of India (NAI). File No. 114/CF/46. 26 February 1947.
} 
and both Dundas and Singh reminded the cabinet that 'when these troops are withdrawn, they will have to be demobilised and some 82, 540 men will be thrown out of employment'. Auchinleck hoped that the army would remain united and shared his fears otherwise with the Commonwealth Relations Office (CRO) in London:

I have no idea... whether India will stay in the Commonwealth...I and all my senior commanders and staff officers are most anxious at the way in which the politicians (and some of the senior Indian officers) are trying to force the pace of nationalisation [of the army]. ${ }^{49}$

At this time in March 1947, there were 13, 500 British officers in the Indian Army to 8, 500 Indian officers. Mountbatten who had come to India with a political brief as opposed to a military one was quick to side-line the sentimental Auchinleck at the altar of his negotiations with the pragmatic Indian politicians. John Connell, Auchinleck’s pre-eminent biographer, has summed the turn-around in Auchinleck's fortunes thus:

There is no evidence to show that, after April 25, the C-in-C was consulted again as to policy... This is not to be construed as a deliberate affront...it was the expression of an extraordinary and unprecedented revolution in fundamental attitudes on the part of the Viceroy. ${ }^{50}$

In fact, it was not just Mountbatten in New Delhi but also the Chief of Imperial General Staff Viscount Montgomery in London who was keen to side-line Auchinleck. Twice in the first six months of 1947, Montgomery wanted to replace Auchinleck with General Slim but Mountbatten did not want to replace the Commander-in-Chief so close to the transfer of

\footnotetext{
49 John Rylands Library (JRL), University of Manchester. MUL 1215, Auchinleck Papers, d/o no. 80/S-3/47/6, Auchinleck to Scoones, 2 March 1947.

${ }^{50}$ Connell, Auchinleck, p. 885.
} 
power. ${ }^{51}$ In mid-June, the Armed Forces Reconstitution Committee was set-up alongside the Partition Council. Soon, Montgomery arrived in Delhi to try to make Auchinleck 'more ready to accept the destruction of his beloved Army'. ${ }^{52}$ Nevertheless, Auchinleck insisted on British officers to be retained during the process of 'reconstitution' so that the goodwill, trust and efficiency of the army would not be impaired by partition. ${ }^{53}$ In July 1947, Sir William Barton of the Political Department of Government of India wrote an article titled 'The Defence of India' in The Fortnightly, which set out 'the danger of withdrawing all British military influence from India: laying the two relatively defenceless [and mutually hostile] dominions open to attack from Russia'. ${ }^{54}$ Yet another summary was prepared by the Defence Department on 1 August 1947 that recommended that all Indian forces abroad 'should be withdrawn in a phased manner by January 1948'. 55

The Chiefs of Staff in London were alive to its implications and, in the Joint Defence Council meeting on 6 August 1947, Mountbatten informed Mohammad Ali Jinnah, Vallabhbhai Patel and others that London was anxious for long-term defence arrangements with and between India and Pakistan. The dominant geographical position of the Indian subcontinent had been prejudiced for the moment by partition and the announced withdrawal of the British forces and therefore mutual defence arrangements were imperative. A military delegation was expected later in the year to put a plan in place. ${ }^{56}$ By now, however, the British were finding

\footnotetext{
51 Ziegler, Mountbatten, p. 463.

${ }^{52}$ Ziegler, Mountbatten, p. 391.

53 See item nos. 216 and 312 of volume XI of TOP.

54 TNA. F 9522, FO 371/63565. 16 July 1947.

${ }^{55}$ NAI. File No. 114/CF/46. 1 August 1947.

${ }^{56}$ HL. MB1/D59/7-11 (Folder 2), Mountbatten Papers. JDC meeting, 6 August 1947.
} 
themselves pitchforked by suspicion from both sides starting with the men on top Mountbatten and Auchinleck. The Partition Council meetings on the division of armed forces were proving more difficult than thought. As Mountbatten shared with one of the provincial governors:

So far we had been working on the basis of communal proportions in dividing the fighting services, the smaller partner by far being Pakistan. In the case of the Army, it worked out at a rough proportion of 70:30. In the case of the Navy, it worked at about 60:40 but as India has a far bigger coastline and more harbours and a far greater proportion of trade to guard, the ships were divided in the proportion 70:30. When it came to the air, the communal proportions worked out at 80:20. As there are 10 squadrons (2 transport and 8 fighter), the Indian representatives claimed 8. However, the Armed Forces Reconstitution Committee had recommended that on the analogy of the naval division, the proportions should be 70:30, since Pakistan had the North-west frontier to guard. The discussion became exceedingly acrimonious...There was an anti-British feeling against the Armed Forces Reconstitution Committee for departing in favour of Pakistan.. ${ }^{57}$

The Congress had been complaining to Mountbatten about Auchinleck's 'pro-Pakistan attitude' in the Joint Defence Council. ${ }^{58}$ Mountbatten maintained that Auchinleck was 'merely trying to be fair'. ${ }^{59}$ This was aan about-turn from only nine months ago, when Baldev Singh had written to Attlee that it was 'imperative that Auchinleck remains for 2-3 years given his good service, popularity with all ranks, invaluable experience, full faith in reorganisation from $2 \frac{1}{1} 2$ million men to $400,000-500,000$ '. ${ }^{60}$ On the other hand, Jinnah had

\footnotetext{
${ }^{57}$ HL. MB1/D1, Mountbatten to Bourne, 5 August 1947.

${ }^{58}$ HL. MB1/D198. Mountbatten Papers. Patel to Mountbatten, 2 August 1947.

${ }^{59}$ HL. MB1/DB4 (Folder 2). Mountbatten Papers. Mountbatten’s personal report no. 15, 2 August 1947.

${ }^{60}$ TNA. PREM 8/583. Baldev Singh to Attlee, 12 December 1946.
} 
told Mountbatten that the Muslim League no longer had faith in Auchinleck. ${ }^{61}$ On his part, Auchinleck thought that 'there might be adverse Muslim comment to Mountbatten staying on as Governor-General of India only’ ${ }^{62}$ Nevertheless, he wanted Mountbatten to continue and offered to resign. ${ }^{63}$ Instead, from 15 August, he became the Supreme Commander of two armies: 'a hope of continuity if no operational control'. ${ }^{64}$ The anomalies of being the 'legally constituted embodiment of British authority after the transfer of power', so as to reconstitute the successor states' armies, were 'many and obvious' ${ }^{65}$ How much this continuity, let alone control, was going to be contested can be seen from an uncompromising letter Nehru wrote to Mountbatten about Auchinleck’s ‘approach relating to the partition of the Army', almost three weeks before the partition of India:

\begin{abstract}
The mere fact that the Supreme Commander will be in administrative control for a limited period does not mean that he will be free to carry out his own ideas. What we have in mind is that he would endeavour...that the transition from the joint administration to our own administration would be smooth and as nearly in accord as possible with our own ideas regarding the future. If this is not clearly understood there is bound to be a conflict. In a way, the Supreme Commander will have the casting vote in the future Joint Defence Council, and if his general outlook is completely different from our own then clearly the Council will not function at all.. ${ }^{66}$
\end{abstract}

\title{
August-November 1947
}

\footnotetext{
${ }^{61}$ Item no. 311 in volume XI of TOP, 23 June 1947.

${ }^{62}$ Item no. 545 in volume XI of TOP.

${ }^{63}$ Item nos. 522 and 557 in volume XI of TOP.

64 Ziegler, Mountbatten, p. 390.

${ }^{65}$ Connell, Auchinleck, pp. 900-01.

${ }^{66}$ NMML. Subject File S. No. 40 (V Installment). Rajagopalachari Papers. Nehru to Mountbatten, 26 July 1947.
} 
The euphoria of independence came to India and Pakistan accompanied with the bitterness of large-scale population movements, refugee problems, massive communal riots and a threat of inter-dominion hostilities over the 'unfinished business of partition', first Junagadh, then Kashmir and possibly Hyderabad. Auchinleck met Mountbatten and pointed out that in case of hostilities breaking out between India and Pakistan, British officers should not be allowed to take an active part in such engagements. ${ }^{67}$ This was just as well for post-14/15 August 1947, senior British officials/officers who continued in the subcontinent inevitably found themselves, what the CRO later termed as, 'taking up cudgels' on behalf of the two dominions. ${ }^{68}$ This was most acutely reflected in the increasingly divergent positions of Mountbatten and Auchinleck, themselves. In this, Auchinleck had scant support from the Chiefs of Staff in London, from where Montgomery did not mince his views or words:

\begin{abstract}
Auchinleck's usefulness in India has finished. He is 63; he has spent all his life in India under a previous regime; he is too old to readjust himself to new ideas, which he dislikes in his heart. He is viewed with suspicion by the senior officers of the Indian Army...I personally consider that if you want military matters to run smoothly and efficiently in India you will have to remove Auchinleck...if you do not do so you will have trouble...69
\end{abstract}

Meanwhile, Nehru's cabinet looked upon its army as 'British-controlled machines' and wished to nationalise it as soon as possible and certainly no later than 1 April 1948. Auchinleck was of the opinion that this would 'ruin the Indian Army which will become an inefficient machine with political affiliations'. On the other hand, Pakistan was already

\footnotetext{
${ }^{67}$ Item no. 113 in volume XII of TOP. Auchinleck-Mountbatten meeting, 15 July 1947.

68 TNA. F 14613/8800/85, FO 371/63570. 1 November 1947.

${ }^{69}$ Ziegler, Mountbatten, p. 463.
} 
offering very good terms to those British officers, who were prepared to resign their British commissions and re-engage with the Pakistan Army. This scenario was complicated by, as Mountbatten reported to London, his personal impression that

\begin{abstract}
...the great majority of British officers have a bias towards the Muslims and although they behave in a perfectly impartial manner it is obvious that they get on better with the Muslims and I shall have to balance out the desirability of retaining British officers with the dominion of India against the ill effects of retaining officers who are neither trusted by the Indians nor trust them. ${ }^{70}$
\end{abstract}

It was his long letter to Mountbatten on 13 September 1947, written against the backdrop of post-partition violence in the Indian capital that proved to be Auchinleck's swan song. In it, he made his feelings plain that 'not one single Muslim in Delhi today believes in the smallest degree in the good faith or intentions of this Government', launched a broadside against the Sikhs and charged the Indian Government with attempts to establish a 'Brahmin Raj'. ${ }^{71}$ Less than two weeks letter, on 26 September, Auchinleck read from Mountbatten a longer missive that confirmed the 'volume of criticism in the Cabinet' against him by Indian ministers resentful of his position and person as 'a derogation of their sovereignty', and, concluded thus: 'I can no longer prevent [the Indian leaders] from putting up an official proposal that the Supreme Headquarters should be abolished and replaced by an organisation with a less highsounding title and headed by less high-ranking officers'. ${ }^{72}$ By now, Mountbatten wanted Auchinleck to go while his reputation held high, for as he informed the Supreme Commander that 'one of the most balanced and level headed [Indian] Ministers complained recently that

\footnotetext{
${ }^{70}$ HL. MB1/D86. Mountbatten Papers. Mountbatten’s personal report no. 1, 2 September 1947.

${ }^{71}$ Major Alexander Greenwood, Field-Marshal Auchinleck (Durham, 1992), pp. 277-78.

${ }^{72}$ Ibid. pp. 279-80.
} 
you seemed to regard yourself as the champion of Pakistan's interests'. ${ }^{73}$ Reacting resentfully, Auchinleck, who wanted to leave not before 31 December, ${ }^{74}$ complained to Attlee that he had

...no hesitation whatsoever in affirming that the present Indian cabinet [whose head was Mountbatten] are implacably determined to do all in their power to prevent the establishment of the dominion of Pakistan on a firmer basis. In this, I am supported by the unanimous opinion of my senior officers, and indeed, by all responsible British officers cognisant of the situation. ${ }^{75}$

At the tenth meeting of the Joint Defence Council in New Delhi on 23 September 1947, Mountbatten informed the Indians and the Pakistanis that reports reaching him indicated that British officers now serving in the two dominion armies were becoming less keen on continuing to serve in view of the recent large-scale disturbances and massacres in Punjab and Delhi as well as the worsening situation in Junagadh. Baldev Singh, India's Defence Minister and ADF Dundas, Pakistan's Defence Secretary, however, stated their opinion that services of British officers would be required during and after the period of reconstitution. Dundas also informed the Council that details as regards the number of British officers required by Pakistan were being worked out and would be available in early October. Mountbatten wanted the two dominions to make a public announcement of terms and conditions, which they were prepared to offer to British officers willing to serve and hoped

\footnotetext{
${ }^{73}$ Kings College London (KCL). File No. 3/7/67, Ismay Papers. DO No. 3/7/67/38, Mountbatten to Auchinleck, 26 September 1947.

${ }^{74}$ Connell, Auchinleck, p. 925.

${ }^{75}$ British Library (BL). India Office records (IOR). F 200/102, Mountbatten Papers. Auchinleck to Attlee, 28 September 1947.
} 
that these would be nearly as identical as possible to avoid competition. ${ }^{76}$ Meanwhile, in a sign of worsening relations between the dominions, Pakistan’s Prime Minister Liaquat Ali Khan had complained to Attlee about India being unfair on post-partition riots, refugee movements and division of assets and requested him to inform other dominion governments about India's behaviour, as well as call a Commonwealth meeting. Attlee refused the latter request but agreed to do the former. Laurence Grafftey-Smith, Britain’s High-Commissioner in Pakistan, who shared Liaquat's feelings, warned the CRO that Pakistan would be

\footnotetext{
...gravely disappointed by the Prime Minister's decision to not meet the Pakistani request for mediatory action by other members of the Commonwealth between India and Pakistan...Pakistan Government feel entitled to invoke the sympathy and interest of other Dominions. ${ }^{77}$
}

Grafftey-Smith considered it embarrassing that if Jinnah's 'moderate and reasonable enough' appeal, of a team of Commonwealth representatives to visit India and Pakistan for joint discussions on present violence, was refused, then the alternative offered by Foreign Minister Zafrulla Khan and Liaquat was to take matters outside the 'family footing' and 'call in outsiders [UNO] to mediate between two members of the Commonwealth'. ${ }^{78}$ A defiant Nehru disagreed with Liaquat's complaints and declined to have either a Commonwealth conference or UN observers. Instead, he wrote to Liaquat demanding 'open and frank' dealings. ${ }^{79}$ On 27 September 1947, with hostilities in Junagadh seemingly imminent, the

\footnotetext{
${ }^{76}$ HL. MB1/D60 (Folder 1). Mountbatten Papers.

${ }^{77}$ Middle-Eastern Centre (M-EC), St. Antony’s College, University of Oxford. Grafftey-Smith Papers GB1650123. File 1/1, No. 56, Grafftey-Smith to CRO, 14 September 1947.

${ }^{78}$ M-EC. Grafftey-Smith Papers GB165-0123. File 1/1, No. 82, Grafftey-Smith to CRO, 23 September 1947.

${ }^{79}$ HL. MB1/D241. Mountbatten Papers. Liaquat to Attlee, 10 and 18 September 1947, Attlee to Liaquat, 15 September 1947 and Nehru to Attlee and Liaquat, 23 September 1947.
} 
Chiefs of Indian Army, Navy and Air Force Rear-Admiral JTS Hall, General RMM Lockhart and Air-Commander S Mukherjee submitted a reluctant paper to Baldev Singh for the attention of the cabinet about the projected operations there. It simply served to confirm Nehru cabinet's frustrations about the continuing presence of British officers in the subcontinent:

\begin{abstract}
There is one other important factor - the position of British officers of all three services, including three armed forces commanders, serving with the Indian forces. These officers belong to the British fighting services and it would be impossible for any of them to take part in a war between the dominions or to be the instrument of planning or conveying orders to others should the operations now contemplated result in such a war or appear likely to do so. ${ }^{80}$
\end{abstract}

The crux of this British military presence was 'the continuation of the post of Supreme Commander [which] rankled with the politicians. [Moreover] many Indians considered Auchinleck to be biased towards Pakistanis' - later vice-versa too when Auchinleck warned Jinnah in November 1947 that 'if he tried to send Pakistani troops to Kashmir, Auchinleck would order all British officers to withdraw from Pakistan army.${ }^{81}$ It was for this reason that Mountbatten was not complaining. He pointed to Nehru that he 'did not regret the present arrangement since it was the fact that the armed forces of both dominions were commanded and so largely officered by the British that was the final barrier against the two dominions being drawn into a war against each other'. ${ }^{82}$ Having failed to keep a united India, Mountbatten's next aim was to keep the divided subcontinent inside the Commonwealth, if possible with a united foreign and defence policy and the British military officers and civil

\footnotetext{
${ }^{80}$ HL. MS 350 A3002/3/2/40, Alan Campbell-Johnson Papers.

${ }^{81}$ Philip Warner, Auchinleck: The Lonely Soldier (London, 1981), p. 222, 225.

82 HL. MB1/D201/25-63. Mountbatten Papers. Mountbatten’s notes on the Junagadh crisis, 29 September 1947.
} 
officials continuing there were the most vital factor for any success. Indeed, the Commonwealth was on everybody's mind. Grafftey-Smith was exhorting the CRO that if Pakistan’s concerns about India were not addressed, ‘...serious thought may be given...to the one basic question mark in the present situation...If [Pakistan's] association with the Commonwealth is of value, then the best possible way of winning their goodwill is by displaying a warmly sympathetic and practical interest in their troubles’. ${ }^{83}$

In response, Archibald Carter, the permanent under-secretary at the CRO, visited Pakistan over 1-3 October 1947 and had a long talk with Jinnah about aid to Pakistan. Jinnah told Carter that his difficulties on the Punjab border and the north-west frontier, in essence not only his interest but the interest of India and of the Commonwealth as a whole, were increased by the fact that he would never get out of India his fair share of the existing military stores and equipment. He hoped to be able to get it from Britain (or the Commonwealth), but if that failed he would have to look elsewhere. Carter replied that while there was general sympathy in London for the initial financial difficulties of Pakistan, long-term defence requirements were a different matter given political difficulties. That is if Pakistan were asking for a form of assistance from Britain, which was not being accorded to India despite the fact that India might not have made any similar request. He did assure Jinnah that the question of frontier defence, as distinct from financial difficulties, raised issues in which the Chiefs of Staff in London would be interested. ${ }^{84}$ Liaquat did not disguise his disappointment at this cool reception given to Pakistan's appeal. It was a cold douche to Pakistan's hopes of

\footnotetext{
${ }^{83}$ M-EC. Grafftey-Smith Papers GB165-0123. File 1/12, No. 97, Grafftey-Smith to CRO, October 1947.

${ }^{84}$ HL. MB1/D240 (Folder 1). Mountbatten Papers. Carter’s talk with Jinnah, 3 October 1947.
} 
fraternal assistance and did little to dispel Pakistan’s suspicions of India's intentions about their existence let along consolidation. ${ }^{85}$

These were also illustrated in Pakistan's 'objections to the Supreme Headquarters being closed down by the $30^{\text {th }}$ November'. Being the weaker party, it reasonably held that 'the consequence of this abandonment would be that [it] could [not] be sure of obtaining [its] fair share of stores held in [India]'. In response, the 'Indian Cabinet [felt] strongly' about the closing down of Auchinleck’s Headquarters, 'which [included] a Field Marshal as Supreme Commander, a Lieutenant General, an Air Marshal and a Vice-Admiral as Deputy Supreme Commanders...otherwise we should be faced with the anomalous position of having more senior officers to look after the interests of British officers than the armed forces of the two Dominions'. ${ }^{86}$ Consequently, Carter went back and prepared his paper on 'Aid to Pakistan’ three weeks later. Ismay, who left India on 3 October 1947, made a statement on the defence situation in India to the Chief of Imperial General Staff five days later and, subsequently, to the Commonwealth Affairs Committee. Carter factored in Ismay's appreciation in his report and later Ismay too commented upon it. ${ }^{87}$ Archibald Carter's note on 'Aid to Pakistan' concluded thus:

It seems almost inevitable that, no doubt with great reluctance, without having any real data on which to calculate the risks involved and without any absolute certainty that even with such help as we can manage to give survival if possible if India become very actively hostile, we must adopt

\footnotetext{
${ }^{85}$ M-EC. Grafftey-Smith Papers GB165-0123. File 1/1, No. 126, Grafftey-Smith to CRO, 13 October 1947.

${ }^{86}$ Selected Works of Jawaharlal Nehru (Second Series, Volume Four) (New Delhi, 1986), pp. 489-90.

${ }^{87}$ HL. MB1/D240 (Folder 1) and MB1/D241. Mountbatten Papers. 8 and 9 October 1947.
} 
the policy of assisting Pakistan so far as our own present difficulties admit and that we must do even at the risk of worsening our present entirely friendly relations with the Indian government. ${ }^{88}$

Ismay’s comment was only slightly more ambiguous:

\begin{abstract}
Are we going to treat both dominions in precisely the same way or are we going to treat any request from either of them on their strict merits? It seems fantastic that Pakistan should be prevented from having any assistance merely because India does not require that particular form of assistance. Indeed, it would be only too easy for India to prevent Pakistan having anything at all by saying - "you must not favour them at our expense”. 89
\end{abstract}

While all this was going on in London, India and Pakistan were coming closer to hostilities in Kashmir with each passing day. Mountbatten, Auchinleck and the Chiefs of Staff had agreed to issue orders to British officers requiring them to 'stand down' in the event of a conflict between India and Pakistan. ${ }^{90}$ These orders were discussed by the Commonwealth Affairs Committee of the Attlee Cabinet on 13 October 1947. The committee, while in general agreement with Auchinleck and his powers to issue 'stand down' orders, felt it 'most desirable that [HMG] should, if possible, be consulted before the decision was taken' and asked Auchinleck to 'make every effort to do so'. Further, the Supreme Commander was instructed to 'consult with the United Kingdom High-Commissioners in India and Pakistan before taking any action himself or making a submission to [HMG]'. ${ }^{91}$ Thus began, in the

\footnotetext{
${ }^{88}$ HL. MB1/D240 (Folder 1). Mountbatten Papers. 23 October 1947.

${ }^{89}$ HL. MB1/D240 (Folder 1). Mountbatten Papers. 23 October 1947.

${ }^{90}$ BL, IOR. File L/WS/1/1138, Auchinleck to UK Chiefs of Staff (CoS), 28 October 1947. On the question of ‘stand down’ see Rakesh Ankit, ‘To issue “stand down” or not...: Britain and Kashmir, 1947-49’, Britain and the World, 7: 2 (2014), pp. 238-260.

91 TNA. CAB 134/54. 13 October 1947 and PREM 8/800, Attlee to Auchinleck, 15 October 1947.
} 
first fortnight of October 1947, a sequence, which eventually ended Auchinleck's stay in India, with the closure of his office of the Supreme Headquarters of the Armed Forces of India and Pakistan. The clinching factor was Mountbatten's progressive nod towards the Indians in the deepening distrust between Nehru’s government and Auchinleck. Mountbatten was helped in this by the senior-most British officers commanding the Indian Army, Rob Lockhart and Roy Bucher. When asked whether they would sooner face administrative chaos as a result of Auchinleck's Supreme Headquarters closing down on 30 November 1947 or have a better shot at 'reconstitution' by having Auchinleck’s offices until the end-of-the-year, Bucher's reply could not be clearer:

I am certain that Rob and I would sooner face the administrative chaos than keep this appalling set-up one unnecessary day. We can always disentangle chaos but we cannot undo the mischief that they are doing every day to British-Indian relations, for every day that Claude stays here, he is undermining his own great reputation not only with all the Indians but, I am sorry to say with all the British who are not in his own HQ. I consider the 30 November the latest possible date for him to stay and would have thought he could have got out by 30 October. ${ }^{92}$

Rob Lockhart too, concurred and, sharing their appreciation with the just-departed Ismay, Mountbatten also revealed that Roy Bucher had told him that Auchinleck and Frank Messervy, Pakistan’s Commander-in-Chief, had forced Lockhart to recommend to London the desirability of the continued presence of British officers in India and Pakistan as they would not fight among each other and would be able to arbitrate between the warring dominions. Auchinleck had apparently addressed the British commanders saying

\footnotetext{
${ }^{92}$ HL. MB1/D302. Mountbatten Papers. Mountbatten to Ismay, 6 October 1947.
} 
...you are responsible to me and not to your governments. I am responsible to the British COS to see that there is no war between the two dominions and I intend taking every step to carry this out. At the slightest sign of war, I shall threaten to remove all the officers and if war breaks out, I shall actually do so. Your loyalty is to the HMG through me and not your dominions governments. ${ }^{93}$

Mountbatten was informed of this by Bucher, who, having been informed thus by Lockhart, was worried at this example of Auchinleck taking a hand between India and Pakistan. Mountbatten knew very well that Pakistan would certainly object to the early closing down of the Supreme Headquarters since they, naturally, regarded Auchinleck's office as the only means of getting their 'pound of flesh' out of India. But now, as the Governor-General of India, he was also beginning to argue that it would take up to two years to get Pakistan's stores moved and a month more or less of Auchinleck in India could not make much difference. In any case, the Nehru government was formally pledged to transfer one-third of the stores to Pakistan given the necessary financial adjustments and Mountbatten was confident that Pakistan would get its share unless, of course, 'the situation deteriorates even more', which was an ever-present threat in the autumn and winter of 1947.

By the end of the first week of October, the positions of each of the main protagonists were clear: to Auchinleck, 30 November was alright as the cut-off date for the division of Navy and Air Force but, for the 'reconstitution' of Army, with the British officer's contract expiring only on 31 December that was the more suitable date. Moreover, he was convinced that he was the only officer in India that the British officers and the Pakistan government trusted, and nobody could take his place since 'he would be pushed around' by the Congress. For Arthur Smith, widely expected to be Auchinleck’s successor, it was impossible to close

\footnotetext{
${ }^{93}$ HL. MB1/D302. Mountbatten Papers. Mountbatten to Ismay, 6 October 1947.
} 
down the Supreme Headquarters before the end of the year 'as British interests would suffer'. On the other hand, Bucher, Lockhart, Elmhirst and Hall - British officers serving the Nehru government - were all 'willing and anxious' to take over not later than 30 November $1947 .{ }^{94}$ Mountbatten called Auchinleck on 7 October and told him, in a difficult interview, that on account of 'dignity, practicality, finance and Indian opposition', he should leave by 30 November 1947. Nor could he recommend Arthur Smith as his successor, given the cloud of suspicion above his head. Arthur Smith had been reported to proclaim at Auchinleck's house, 'yes, ask any British officers of Lt Col [and above] rank in this room and they will tell you that they are pro-Pakistan'. Baldev Singh did not want him at the Supreme Headquarters. Auchinleck responded by making it clear that if he was pushed out then he would withdraw every British officer or other ranks with the two dominions in case of a conflict between them or between India and Hyderabad. He had already threatened Lockhart that he would transfer him to Pakistan or sack him given his involvement in Indian Army’s plans in Junagadh. Mountbatten's sentiment was definitely not genuine, but his sense was correct when he wrote to Ismay: 'My heart bled for “Auk”, he minds it all so much...' ${ }^{95}$ - his heart did not bleed for Auchinleck, but the latter definitely minded it all very much.

Mountbatten had agreed with Auchinleck insofar as withdrawing British officers and other ranks employed in India and Pakistan in case of a conflict was concerned. But he felt that it should be done through the CRO in London and their High-Commissioners in New Delhi and Karachi, more tactfully rather than as a show of strength by Auchinleck's Supreme Headquarters. He had provisionally prevailed upon Auchinleck 'after most friendly discussion' about the date of closure, 30 November, subject to the British Chiefs of Staff's

\footnotetext{
${ }^{94}$ HL. MB1/D196A. Mountbatten Papers. Mountbatten to Ismay, 7 October 1947.

${ }^{95}$ HL. MB1/D196A. Mountbatten Papers. Mountbatten to Ismay, 7 October 1947.
} 
decision. ${ }^{96}$ It was a decision which did not take too long to come with Ismay and Montgomery supporting Mountbatten’s position in London. ${ }^{97}$ On 9 October 1947, Jinnah was presented with the fait accompli by Auchinleck and took it philosophically: 'Kismet [fate]; I do not like it but we must bow to the inevitable'. ${ }^{98}$ Auchinleck now reluctantly prepared a note, which was discussed at the Joint Defence Council on 16 October 1947. Officially and publicly, Auchinleck gave four reasons for the closure: a) the progress made in the 'reconstitution' of the armed forces, b) the ability of the armed forces of the two dominions to take over, c) the control and maintenance of the armed forces of the two dominions which are still overseas and d) the repatriation of the British units and their families. The real reasons, as he wrote to the Minister for Commonwealth Relations, Philip Noel-Baker, were the 'absence of the necessary cooperation, harmony and goodwill between the parties concerned; obdurate attitude of the Government of India towards the Supreme Commander's Headquarters and India's refusal to cooperate [in the] impartial discharge of duties'. ${ }^{99}$ Rather obliquely, Auchinleck noted that 'the situation existing today in the subcontinent differs radically from that which was confidently expected to result from partition' and, therefore, he was finding it increasingly hard to carry out his task owing to the difference of opinion between the two governments and a lack of common ground for cooperation. ${ }^{100}$ Difference of opinion between the governments of India and Pakistan was one thing and was substantial enough but the bigger nail in the coffin of the Supreme Headquarters was the attitude evinced towards it by a 'virulent' Patel and a 'hostile' Nehru. To them, the Indian Army, as it existed

\footnotetext{
${ }^{96}$ HL. MB1/D302. Mountbatten Papers. Mountbatten to Ismay, 7 October 1947.

${ }^{97}$ HL. MB1/D302. Mountbatten Papers. 8 October 1947.

${ }^{98}$ HL. MB1/D302. Mountbatten Papers.

99 JRL. MUL 1276-77, Auchinleck Papers. 270021/DSC, Auchinleck to Noel-Baker, 30 October 1947.

${ }^{100}$ HL. MB1/D50 (Folder 1). Mountbatten Papers. 13 and 16 October 1947.
} 
was nothing but a 'British instrument designed to be commanded by British officers to implement British policy’. As Patel told Mountbatten:

\begin{abstract}
Supreme HQ [is] throttling the initiative of Indian Army and acting as the advanced outpost of Pakistan. They may think they are acting impartially but as they are all mentally completely proPakistan, they are in fact out to help Pakistan at every turn. The longer you leave Auchinleck and his HQ here, the more seriously will the friendship between the British and India be impaired. ${ }^{101}$
\end{abstract}

Patel's long-time secretary V. Shankar (ICS) would, later, confirm that the 'Sardar felt that Auchinleck's organisation was not as impartial as he should have been' and claim that it was 'mainly through his [Patel's] insistence, the post of Supreme Commander was abolished'... ${ }^{102}$ Over September-October 1947, Patel especially minded Auchinleck’s alleged 'subscription to the view that refugee traffic could be possibly resumed in both directions if the Sikhs could be effectively disarmed' and enquired from both Mountbatten and Auchinleck. ${ }^{103}$ Thus, what Attlee would term 'the latest of many services' that Auchinleck did in India, the triple responsibility of division of the former army, welfare and withdrawal of remaining British soldiers and the maintenance of law and order especially in the Punjab, ${ }^{104}$ saw him clash squarely with the Indian leaders.

Unlike Jinnah, Liaquat had objected to Auchinleck's proposal of closing down his Headquarters by 30 November in the Joint Defence Committee meeting held at Lahore on 16 October. To Mountbatten, Liaquat admitted that he did not believe that anyone, but a British

\footnotetext{
${ }^{101}$ HL. MB1/D86. Mountbatten Papers. Mountbatten’s personal report no. 4, 10 October 1947.

102 V. Shankar (ed.), Select Correspondence of Sardar Patel 1945-50 (Volume I) (Ahmedabad, 1977), p. 114.

${ }^{103}$ Durga Das (ed.) Sardar Patel: Correspondences (Volume IV) (Ahmedabad, 1972), pp. 288-90.

${ }^{104}$ Connell, Auchinleck, p. 901, 936.
} 
Supreme Commander could ensure his getting stores from India. He was not satisfied by Baldev Singh's promises or even the entire Nehru cabinet's orders as 'lower-level Indians would sabotage the orders of their own government to defeat Pakistan'.. ${ }^{105}$ Nevertheless, the juggernaut rolled on. On 19 October, Nehru formally informed Liaquat about the closing down of Auchinleck's office by 30 November 1947. ${ }^{106}$ Liaquat replied indignantly accusing India of 'lack of cooperation' and giving an 'incorrect and misleading impression'. He said that the Supreme Commander had been 'carrying out his duties in an entirely impartial manner', but that the Government of India did not 'favour continuance of an impartial authority for carrying out fully the reconstitution of the armed forces'. ${ }^{107}$

Writing to Ismay after the critical and cantankerous meeting of the Joint Defence Council on 16 October, Mountbatten narrated the entire act. Baldev Singh had proved immovable on not just Auchinleck, but the existence of the office of Supreme Commander itself. He told Mountbatten that the Congress suspected that Auchinleck wanted to appoint Arthur Smith to succeed him and, if anything, the Congress mistrusted Arthur Smith even more than Claude. Calling Smith, the 'pro-Pakistan evil genius', Baldev went so far as to say that they would sooner keep Auchinleck than Smith. ${ }^{108}$ Given this insurmountable opposition from his own government, Mountbatten had 'bullied' Auchinleck and brought pressure to bear upon him to not just advance the date of his own departure from 31 December to 30 November but also for the closing down of the Supreme Commander's Headquarters. Liaquat's vehement opposition was side-lined and Mountbatten sought to manage him by agreeing 'to try and get

\footnotetext{
${ }^{105}$ HL. MB1/D50 (Folder 1). Mountbatten Papers.

${ }^{106}$ HL. MB1/D50 (Folder 1). Mountbatten Papers. No. 358/PRIMIN/178, Nehru to Liaquat, 19 October 1947.

${ }^{107}$ HL. MB1/D50 (Folder 1). Mountbatten Papers.

${ }^{108}$ HL. MB1/D302. Mountbatten Papers. 17 October 1947.
} 
the whole of Indian cabinet to endorse the pledge that stores will be transferred'. Mountbatten also pointed it out to Liaquat that, in any case, if India did not intend then whoever was the Supreme Commander would be anyway powerless. As London and New Delhi had agreed, there was nothing more Pakistan could do about it. Moreover, as India owned the Supreme Headquarters' buildings and were responsible for two-thirds of the staff pay, their insistence could not be resisted. Nehru, Patel and Baldev Singh preferred the British Commander-inChief of dominion forces to be responsible for their British officers to themselves or to London but not to any form of Supreme Headquarters. ${ }^{109}$

Auchinleck, however, had not yet given up and Mountbatten braced himself for 'another tussle with Claude'. In the event, he had 'grossly underestimated the scene [he] was in for'. The bone of contention was that Mountbatten had hastened to send Auchinleck's paper on the closure of his office discussed at the previous Joint Defence Council meeting to the Chiefs of Staff in London via Ismay. When Mountbatten revealed this to Auchinleck, the latter 'completely blew off'. When told that the Congress wanted their own Commander-in-Chiefs to look after British interests, in addition to India's, he 'blew up again' and when finally informed that the Nehru government would not have Arthur Smith, 'the lid blew completely off'. It proved hard for Mountbatten to convince Auchinleck that they were both on the same page and the Governor-General was trying to help. ${ }^{110}$ Ismay lent a helping hand to Mountbatten in biding over the 'troublesome time with Claude' by asking him to assure Auchinleck that the Attlee Government was 'looking into the question of Pakistan's unofficial request for financial assistance and for help in obtaining military stores and equipment'. General Messervy had arrived in London on 20 October 1947 with proposals

\footnotetext{
${ }^{109}$ HL. MB1/D196. Mountbatten Papers. Mountbatten to Ismay, 17 October 1947.

${ }^{110}$ HL. MB1/D303. Mountbatten Papers. Mountbatten to Ismay, 18 October 1947.
} 
about British officers continuing in Pakistan in 1948. Of course, this raised political issues to be resolved keeping in mind India, from where their nominees were also arriving shortly in London with the Indian proposals. ${ }^{111}$ When they did, they complained that many of the difficulties, which they had met in the course of the negotiations had been due to the fact that Messervy had already reached an agreement accepting provisions, which were unacceptable to New Delhi.. ${ }^{112}$

A bitter Auchinleck was not mollified. Sending his report to the CRO he did not mince his words and squarely held the Indian government as 'the people who have made the present position impossible and they are the people who would like to get control over the British officers and other ranks who will still remain after I go'. ${ }^{113}$ In the ultimate analysis, above every other factor, was 'the hostile atmosphere in Delhi', which Auchinleck held to be the reason for his recommendation that his office may be closed down prematurely, thus bringing to a sad end his forty-four year association with the Indian Army. ${ }^{114}$ As he prepared to go, he also trained his guns at Mountbatten and told the Defence Minister AV Alexander that with respect to the situation in India, in his experience, 'the most serious aspect [was] the way in which British - even Lord Mountbatten himself - are being forced to take sides...This gravely affects British ability to exercise a moderating influence'. ${ }^{115}$ Auchinleck, therefore, asked for a withdrawal of British officers from India and Pakistan especially as, by now, the crisis in Kashmir had begun and Indian troops had been air-lifted bringing uncomfortably

\footnotetext{
${ }^{111}$ HL. MB1/D303. Mountbatten Papers. Ismay to Mountbatten, 20 October 1947.

${ }^{112}$ HL. MB1/D43. Mountbatten Papers. 20 November 1947.

113 JRL. MUL 1271, Auchinleck Papers. D/o no. 80/S-1, Auchinleck to Geoffrey Scoones, 21 October 1947.

114 JRL. MUL 1273, Auchinleck Papers. Auchinleck to Scoones, 24 October 1947.

115 TNA. FO 371/63570. 270028 DSC, Auchinleck to Alexander, 3 November 1947.
} 
close the unprecedented reality of British generals, officers and soldiers on both sides planning and fighting battles with each other. Alexander refused the proposal because 'it would be a confession of Britain giving up'.. 116

Mountbatten had to agree with Auchinleck that preparation of plans for war with another dominion was not part of the contract of British officers in India and Pakistan and, in event of open hostilities between India and Pakistan in Kashmir, they would have to be relieved immediately. He asked Nehru to ensure that 'plans and preparations for war against [Pakistan] should not be undertaken by anyone, either Indian or British', for Mountbatten was also aware that such a move would have 'wider implications' that is, first and foremost, affecting feelings towards Britain in Pakistan, the weaker, more fragile and vulnerable state and second, for the defence of the Commonwealth vis-à-vis the Soviet Union. ${ }^{117}$ British officials in Peshawar, Rawalpindi and Karachi had kept the CRO well-informed about the potential danger of any decision withdrawing British officers from Pakistan being regarded as 'having let down Pakistan' in a moment of crisis. ${ }^{118}$ By November 1947, there was a perceptible growth of anti-British feeling in many quarters in Pakistan for post-partition troubles. ${ }^{119}$ During the infamous episode of Gracey refusing Jinnah’s orders to send Pakistan troops into Kashmir in late-October 1947, without a reference to Auchinleck and the latter flying up to

\footnotetext{
116 TNA. FO 371/63570. 270029 DSC, Alexander to Auchinleck, 4 November 1947.

${ }^{117}$ HL. MB1/D182. Mountbatten Papers. Mountbatten to Nehru, 1 November 1947.

${ }^{118}$ HL. MB1/D240 (Folder 1). Mountbatten Papers. CB Duke to Grafftey-Smith, 5 November 1947.

${ }^{119}$ HL. MB1/D240 (Folder 1). Mountbatten Papers. Grafftey-Smith to Carter, 6 November 1947.
} 
Lahore to prevail upon Jinnah in the first days of November, ${ }^{120}$ Robert Francis Mudie, who had stayed on as Governor in West Punjab, was supposed to have remarked:

\begin{abstract}
Why the hell Gracey was not carrying out Mr Jinnah's orders? What had it got to do with the Supreme Command? What did it matter if the British officers were withdrawn? Could he not send the troops on without British officers? ${ }^{121}$
\end{abstract}

It was all over on 8 November 1947 in the fourteenth meeting of the Joint Defence Council in New Delhi. The meeting considered a telegram from Noel-Baker which stated that, in view of the situation, which had arisen and of the representations of Auchinleck, His Majesty's Government had reluctantly come to the conclusion that it had no option but to withdraw the British officers and other ranks, including the Supreme Commander himself, forming Supreme Commander's Headquarters from India. The result of this would be that Auchinleck's headquarters would cease to exist on 30 November 1947. Mountbatten remarked that he regretted that this subject had caused controversy. He personally believed that it was the right decision and, in view of the unanimous endorsement given by the Indian cabinet to the pledge that India would deliver to Pakistan the latter's full share of stores, Pakistan’s principal objection had been met. Abdur Rab Nishtar, Pakistan’s representative and Communications Minister, made it clear that in his government's opinion this decision was very unfair to Pakistan. Supreme Commander's Headquarters had been set up to 'reconstitute' the Armed Forces. This process had not been completed and the movement of stores had hardly finished. He wished to make it clear that Pakistan were not a party to the

\footnotetext{
${ }^{120}$ For an early account of this and other examples of the British being caught in a binary, see Lord Birdwood, Two Nations and Kashmir (London, 1956).

${ }^{121}$ HL. MB1/D87. Mountbatten Papers. Mountbatten’s personal report no. 5, 7 November 1947.
} 
decision. This had been forced upon Pakistan without their consent and in spite of the views they held and had declared. ${ }^{122}$ On his part, Auchinleck accepted a small farewell lunch on 25 November, stayed a night with the Mountbattens and flew out of Delhi on 1 December at the age of 63. As he later put it in an interview, 'one felt the whole time that one was killing an entity which had existed for a good many hundred years and with which you had spent the whole of your working life...It was the end of all things for an old Indian Army officer like myself'. ${ }^{123}$

\section{Conclusion}

Within a week of Auchinleck's departure, Grafftey-Smith was reporting the 'language of disillusion' in Pakistan towards the 'falsity of the allegedly "family” relationship existing within the Commonwealth'. He regretted London's decision in view of the fact that there was 'no precedent for a situation fringing war between two members of the Commonwealth' and concluded pessimistically:

\footnotetext{
It would be unrealistic to pretend that Great Britain and the Commonwealth have not lost a great body of goodwill and friendship in this Dominion by allowing constitutional etiquette to outweigh the claims of family relationship...It would be certainly be unfortunate if any impression prevailed in London that their present silence means that the matter has been forgotten.. ${ }^{124}$
}

Mountbatten and his staff now turned their attention to the next-best scenario: to salvage the consolation of joint defence arrangements between India and Pakistan from the wreckage of

\footnotetext{
${ }^{122}$ HL. MB1/D61 (Folder 1). Mountbatten Papers. 8 November 1947.

${ }^{123}$ Roger Parkinson, The Auk: Auchinleck, Victor at Alamein (London, 1977), p. 250.

${ }^{124}$ M-EC. Grafftey-Smith Papers GB165-0123. File 1/1, S/9/47, Grafftey-Smith to Carter, 5 December 1947.
} 
Auchinleck's headquarters. Mountbatten hoped that the Joint Defence Council would eventually become a joint arrangement for defence, as his constitutional adviser Morris Jones had suggested, along the lines of Australia and New Zealand. ${ }^{125}$ Erskine Crum prepared a note and sent it to India’s Defence Secretary HM Patel. But there was no enthusiasm for it. This was going to be a difficult brief at the best of times but with daggers drawn in Kashmir, December 1947 was a singularly inopportune moment. VP Menon let Brockman know that Nehru's ministers were unlikely to heed this.. ${ }^{126}$ Mountbatten nevertheless, rather characteristically, remained confident. He shared it with Auchinleck as he knew that the latter would be pleased to know if India and Pakistan were beginning to get together on the question of defence. Perhaps betraying a troubled conscience or maybe merely displaying minimum courtesy, Mountbatten wrote a detailed letter to Auchinleck assuring him that 'every outstanding point of difference between the two dominions in the Partition Council and the Joint Defence Committee has been taken out of the hands of the Arbitral Tribunal and a friendly compromise solution found':

\footnotetext{
For instance, although India had only given Pakistan 20 crores out of the cash balance, they have now given a further 55 crores and 9 crores on a debt repayment, making 84 crores cash out of their total holdings of 400 . Similarly, Pakistan, who had only accepted $7 \%$ of uncovered debt to a unified India, have voluntary advanced this to $17.2 \%$ and India has given them 4 years moratorium and 50 years to pay it back. Hyderabad is now settled, a plebiscite has been agreed on for Junagadh and we are left with only one problem - Kashmir. Here again...I see some prospect of a solution, though unfortunately not in the immediate future. ${ }^{127}$
}

\footnotetext{
125 Ziegler, Mountbatten, pp. 464-65.

${ }^{126}$ HL. MB1/D199. Mountbatten Papers. VP Menon to RV Brockman, 6 December 1947.

${ }^{127}$ HL. MB1/D106. Mountbatten Papers. Mountbatten to Auchinleck, 12 December 1947.
} 
Auchinleck’s concern about British generals, officers and other ranks in India and Pakistan slowly getting ranged against each other was not unfounded. Lt General Russell, Generalofficer-Commanding Delhi and East Punjab Command paid a four-day visit to Kashmir in December 1947 with the approval of Nehru and Lockhart but without the knowledge of Arthur Smith, who promptly reported this development to the British High-Commissioner. Smith pointed out that while there could be 'no legal objection to such a visit and [in fact] it was desirable on military grounds', there had to be a 'political [objection] particularly in view of the Secretary of State's assurance to the [leader of opposition] Mr. Churchill on 30 October that "British officers would not be employed in combatant capacities on either side in this dispute”'.. ${ }^{128}$ However, as Russell's visit had not received undue publicity and Lockhart assured that there was no intention to employ British officers as commanders in the field, the High-Commission recommended to the CRO that it seemed 'best to take no notice of it' as 'presumably “combatant” in above assurance [was] to be regarded as referring only to actual fighting in the field and was not intended to cover visits of British Generals or Staff Officers or technical officers to Kashmir'. After all, on both sides they had responsibility for plans in connection with military operations in Kashmir as well as for the welfare of troops engaged and perhaps it was best to not raise any objections. In any case, from January 1, 1948, service of British officers in Indian and Pakistani forces was to be governed by terms of new agreement with the dominions governments. Alexander replied to Mountbatten that it was okay as ‘Russell’s visit seems to have passed off quietly and without comment on either side but it would in my opinion be inadvisable to regard it as a precedent'. ${ }^{129}$ Mountbatten accordingly informed Lockhart and Elmhirst on 23 December and told the HighCommissioner that he agreed with London's suggestion.

\footnotetext{
${ }^{128}$ HL. MB1/E158. Mountbatten Papers. T. No. 1404, Shone to CRO, 10 December 1947.

${ }^{129}$ HL. MB1/E158. Mountbatten Papers. Shone to Mountbatten, 23 December 1947.
} 
Nevertheless, Mountbatten did raise the topic of India and Pakistan coming to a joint arrangement on defence 'keeping in mind Russia' in the seventeenth meeting of the Joint Defence Council in New Delhi in early 1948. Nehru responded to that by saying that defence was the outcome of external policy and could not be considered alone and divorced from that. Until the external policies of India and Pakistan fitted in together, joint defence was difficult to determine. Liaquat agreed with Nehru that India and Pakistan first needed to coordinate their foreign policy. Mountbatten mentioned the possibility of a British Military Delegation, which intended to come to India and Pakistan to discuss Commonwealth defence. This had been pending for long as Attlee had wanted this to happen even before the transfer of power. On this, both Prime Ministers continued to stall. ${ }^{130}$ The Joint Defence Council itself was coming to an end. The nineteenth and last meeting was held on 19 March 1948 at New Delhi and it ceased to exist from 1 April 1948. ${ }^{131}$ Mountbatten himself was initially supposed to leave on this date but, as Auchinleck sardonically put it to Ismay, he “"allowed” himself to be "persuaded" to stay on till June'. Auchinleck was not alone in wondering as to what was 'really on his mind?' ${ }^{132}$ As Philip Ziegler, Mountbatten's official biographer, puts it, Auchinleck like most British officers may have preferred Muslims to Hindus but as an honourable man, he struggled nobly to be impartial - not an easy task in 1947. Perhaps, as suggested, he was 'less agile in mind and tractable in manner' and thus less able to circumvent his prejudices. ${ }^{133}$ To his own biographers, Auchinleck, 'victor at Alamein', 134

\footnotetext{
${ }^{130}$ HL. MB1/D61 (Folder 1). Mountbatten Papers.

${ }^{131}$ HL. MB1/D200. Mountbatten Papers.

${ }^{132}$ KCL. Ismay Papers. IV/CONN/I/2, Auchinleck to Ismay, 30 January 1948.

133 Ziegler, Mountbatten, pp. 390, 462-63.

${ }^{134}$ Parkinson, The Auk.
} 
'the least political of all soldiers', was 'the lonely soldier...tragically solitary' through the ordeal(s) of transfer of power and transition of army. ${ }^{135}$ To Pakistanis, his hastened and enforced departure was one more illustration of Mountbatten's partiality towards the Indians. To Indians, Auchinleck’s views proclaimed after 1947 simply confirmed their earlier mistrust of him. In 1948, Auchinleck prophesised 'a general decentralisation and break-up of the idea that India is a country... The British tried to consolidate it but achieved nothing permanent. No one can make a nation out of a continent of many nations'. ${ }^{136}$ It was precisely the task that Nehru and Patel were engaged in and they were not sorry to see him go.

\footnotetext{
${ }^{135}$ Warner, Auchinleck; Connell, Auchinleck, p. 785.

${ }^{136}$ Guha, India after Gandhi, p. 744.
} 